\title{
Cost of managing COVID 19 patients in a tertiary care hospital in Sri Lanka
}

Ranga SDUM, Dilrukshi DARK, Abeysekara CM, Obeysekara S.

\begin{abstract}
Introduction: COVID-19 is caused by Severe Acute Respiratory Syndrome coronavirus 2 and it spread throughout the world and turned into a severe global pandemic in 2020. The severity of the COVID-19 is wide, ranging from asymptomatic to severe illness that requires mechanical ventilation. Although the curative sector response of Sri Lanka was somewhat different from other countries, it was remarkably effective in preventing community spread.
\end{abstract}

Objective: To assess the average cost of treating Covid 19 patients at Covid Treatment Centre (CTC) in District General Hospital (DGH) Hambantota.

Methodology: This retrospective costing study was conducted in CTC at DGH, Hambantota in December 2020. The step-down costing method was used in this study. Key informant interviews with the accountant, deputy director, and staff of CTC, reviewing expenditure records of the accountant's office, visiting and taking measurements of the floor area, reviewing relevant literature were used to gather data in this costing study.

Results: The average cost of treating a Covid 19 patient per day at CTC, DGH Hambantota was Rs 2317.60.

The total cost of treating a Covid 19 Patient at DGH Hambantota for 10 days was Rs 23176.00. The cost of treating Covid patients at CTC, DGHH was exceptionally low when compared to other countries.

Discussion and conclusion: Treating Covid 19 patients is an economic burden to any health system. Treatment cost was extremely low at DGH, Hambantota and only about 23000 rupees was spent for one patient for 10 days. Drug cost was comparatively low and transport cost was relatively high.

Keywords: Cost, Covid 19, Drug expenditure

\section{Introduction}

COVID-19 is caused by Severe Acute Respiratory Syndrome coronavirus 2 (SARS-CoV-2) is a public health threat worldwide [1]. The 1st case of COVID 19 was reported in Sri Lanka on 27 January 2020, a 44-yearold female Chinese national was admitted to the National
Institute of Infectious Diseases. Since then, there were no cases until her recovery. The first confirmed locally acquired case of COVID 19 in Sri Lanka was reported on 11 March 2020 and the individual was a tour guide for travelers from Italy (2). Thereafter, several cases were reported from Sri Lanka.

As of 30 January 2021, a total of 65000 human COVID-19 cases had been reported in Sri Lanka. The severity of the COVID-19 is wide, ranging from asymptomatic to severe illness that requires mechanical ventilation [3]. Most infected people with COVID-19 are asymptomatic or causing mild-to-moderate disease, whereas the mortality rate is high in patients affected by the severe disease [4]. Covid 19 patients with critical illness, need application of unaffordable respiratory supporting devices which carries a high-cost burden for patients and governments (5).

Although the curative sector response of Sri Lanka was somewhat different from those of other countries, it was remarkably effective in preventing community spread. Admitting all COVID 19 positive patient, without considering the severity of disease to COVID 19 treatment hospitals, admitting COVID 19 suspected patients only to designated hospitals, and preventing admission of COVID 19 patients into private sector hospitals were highly successful measures. Currently, there are 72 Covid treatment and intermediate care centers in Sri Lanka.

The economic impact of the COVID-19 pandemic is extremely high in middle-income countries including Sri Lanka due to the disruption of main incomes like tourism, garment industry, and salaries of foreign employees. However, there are a few studies aimed at quantifying the direct medical costs incurred by COVID19 patients.

To address this public health problem, this retrospective study conducted a cost analysis to determine the medical costs of treating COVID-19 patients in Sri Lanka. This cost analysis study was conducted at Covid treatment center (CTC) at DGH, Hambantota which is one of the nine tertiary care treatment centers in the country. There are 270 beds and 7 ICU beds available at CTC in DGH, Hambantota. 


\section{Objective}

To assess the average cost of treating Covid 19 patients at CTC in DGH, Hambantota.

\section{Methodology}

This retrospective costing study was conducted in CTC at DGH, Hambantota in December 2020. This study setting was selected by using convenient sampling methods. CTC was filled with patients during last November, December, and January and the total numbers were similar during those three months. Therefore, the middle month, December was considered for the study.

The step-down costing method was used in this case study. This method contains the following steps;

1. Identification of final cost centres (i.e. the accounting objects to be costed).

2. Identification of intermediate cost centres (i.e. cost pools which are not relevant in themselves directly but serve as a step for allocating costs to final cost centres).

3. Identification of the relationships between intermediate and final cost centres, and allocate the intermediate costs to final cost centres.

Key informant interviews with the accountant, deputy director, and staff of CTC, reviewing expenditure records of the accountant's office of the DGH, Hambantota, taking measurements of the floor area of Covid treatment centre, reviewing relevant literature were used to gather data in this costing study.

The average cost was calculated in this costing study by considering final, intermediate, and overhead costs. However, the capital costs like land value, building value and equipment cost were not considered.

Estimation of the costs involved.

Expenditure for drugs and PPE, expenditure for PCR and other investigations, expenditure for meals of the patients were considered as the final costs involved in treating the Covid 19 patients.

Staff salaries, expenditure on utilities - water, electricity, cleaning services and security service, expenditure for transport and miscellaneous costs were considered as intermediate and overhead costs.

The CTC is situated in the old hospital premises at DGH, Hambantota. It obtains water and electricity from a separately metered sources. Janitorial services and security services to the CTC and DGHH were provided by same providers and expenses are in common bill. Therefore, expenses for janitorial services and security services were apportioned according to the floor area of CTC. Total inpatient days during December 2020 was 7164. This was used to calculate the unit cost.

The cost for the drugs, PPE and surgical consumables was calculated by using respective consumption records at wards and using the medical supply information management system (MSIMS). Cost for the PCR and other investigation was calculated by using market value, since calculating a real value for investigation is difficult in the government sector. Expenditure for patient meals was calculated by using the cost for raw materials purchase, gas consumption and other consumables.

A deputy director, 2 consultants, 5 medical officers, 20 nursing officers and 15 health care assistants are working in the CTC. Cost for their salaries was obtained from payroll. Electricity, water, telephone, janitorial and security service costs are overheads involved. Cost for electricity, water and telephone was obtained directly from respective bills. Security service and cleaning service costs are apportioned according to the floor area.

$$
\begin{aligned}
\text { The floor area of CTC } & =4 / 10 \text { of the total wards floor } \\
& \text { area of the hospital } \\
& =0.4 \%
\end{aligned}
$$

The number of kilometers run by Covid ambulances was calculated by using the DRCs of the drivers. Since the Ministry of Health charges 50 rupees per kilometer for private ambulance usage, total transport cost was obtained by multiplying that value by 50 .

$$
\begin{array}{ll}
\text { Number of Km run by Covid ambulance } & =\mathrm{Y} \\
\text { Total transport cost } & =\mathrm{Y} \times 50
\end{array}
$$

Miscellaneous expenses of CTC were calculated by using the records of the account branch.

As described and calculated in the sections, total costs and the per-patient cost were considered.

\section{Results}

Cost calculation for treating Covid 19 patients was given in following tables. 
Table1: Cost for drugs, PPE and other surgical consumables in December 2020

\begin{tabular}{lr}
\hline Item & Cost (SLR) \\
\hline Drugs & 235,764 \\
PPE and other surgical consumables & 248,163 \\
\hline Total & $\mathbf{4 8 3 , 9 2 7}$ \\
\hline
\end{tabular}

Table 2: Cost for the PCR and other investigations

\begin{tabular}{lr}
\hline Test & Cost (SLR) \\
\hline PCR & 429,000 \\
Haematological investigations & \\
Biochemical investigations & \\
Microbiological investigations & 219,750 \\
X-rays & 10,400 \\
CT & 18,000 \\
ECG & 5,950 \\
\hline Total & $\mathbf{6 8 3 , 1 0 0}$ \\
\hline
\end{tabular}

Table 03: Expenditure for COVID patient meals

\begin{tabular}{lr}
\hline Item & Cost (SLR) \\
\hline Raw provisions for meals & $2,494,214$ \\
LP Gas & 85,561 \\
Other consumables & 234,480 \\
\hline Total & $\mathbf{2 , 8 1 4 , 2 5 5}$ \\
\hline
\end{tabular}

Table 4: Cost for staff salaries at CTC

\begin{tabular}{lrr}
\hline Staff category & Number & $\begin{array}{r}\text { Cost for salary } \\
\text { (SLR) }\end{array}$ \\
\hline Deputy director & 01 & $4,979,135$ \\
Consultants & 02 & \\
Medical officers & 04 & \\
Nursing officers & 19 & \\
Cooks & 02 & \\
Overseer & 02 & \\
Health care assistants & 20 & \\
\hline
\end{tabular}

Table 5: Expenditure for electricity, water and telephone of the CTC

\begin{tabular}{lr}
\hline Overheads & December 2020 (SLR) \\
\hline Electricity & 636,822 \\
Water & 129,588 \\
Telephone & 16,035 \\
\hline
\end{tabular}

Table 06: Janitorial service and security service cost of CTC

\begin{tabular}{|c|c|c|c|}
\hline Overhead & $\begin{array}{r}\text { Total expenditure } \\
\text { of hospital for } \\
\text { December } 2020\end{array}$ & $\begin{array}{r}\text { Percentage } \\
\text { floor area } \\
\text { of CTC }\end{array}$ & $\begin{array}{r}\text { Cost } \\
\text { apportions } \\
\text { to CTC }\end{array}$ \\
\hline Janitorial & 977,048 & 0.4 & 390,819 \\
\hline Security service & $1,019,848$ & 0.4 & 407,939 \\
\hline Total & & & $\mathbf{7 9 8 , 7 5 8}$ \\
\hline \multicolumn{4}{|c|}{ Cost of transport } \\
\hline \multicolumn{4}{|c|}{ Number of Km run by } \\
\hline \multicolumn{2}{|c|}{ Covid ambulances } & $=$ & 119,014 \\
\hline \multicolumn{4}{|c|}{ Total transport cost } \\
\hline \multirow{2}{*}{\multicolumn{2}{|c|}{$($ Cost for $\mathrm{km}=$ Rs 50$)$}} & \multirow{2}{*}{\multicolumn{2}{|c|}{$\begin{array}{l}=119,014 \times 50 \\
=\text { Rs } 5,950,700\end{array}$}} \\
\hline & & & \\
\hline \multicolumn{4}{|c|}{ Miscellaneous expenses } \\
\hline \multicolumn{4}{|c|}{ Miscellaneous expenses of } \\
\hline
\end{tabular}

\section{Cost calculations}

Table 7: Total Cost calculation

\begin{tabular}{|c|c|c|}
\hline Cost Item & \multicolumn{2}{|c|}{ Total cost for CTC (SLR) } \\
\hline Drugs & & 483,927 \\
\hline \multicolumn{2}{|c|}{ PCR and other investigations } & 683,100 \\
\hline \multicolumn{2}{|l|}{ Meals } & $2,813,955$ \\
\hline \multicolumn{2}{|c|}{ Staff salaries } & $4,979,135$ \\
\hline \multirow[t]{5}{*}{ Overheads } & Electricity & 636,822 \\
\hline & Water & 129,588 \\
\hline & Telephone & 16,035 \\
\hline & Janitorial & 390,819 \\
\hline & Security & 407,939 \\
\hline \multicolumn{2}{|c|}{ Transport cost } & $5,950,700$ \\
\hline \multicolumn{2}{|c|}{ Miscellaneous expenses } & 111,287 \\
\hline \multicolumn{2}{|l|}{ Total } & $16,603,307$ \\
\hline \multicolumn{2}{|c|}{ Total number of inpatient days $=$} & 7,164 \\
\hline \multirow{2}{*}{\multicolumn{2}{|c|}{ Cost per inpatient day }} & $=16,603,307 / 7164$ \\
\hline & & $=\quad$ Rs 2317.60 \\
\hline
\end{tabular}

Average cost for treating

Covid 19 patient per day at

CTC, DGH Hambantota $\quad=\quad$ Rs 2317.60

Total cost for treating

Covid 19 patient at DGH

Hambantota for 10 days $\quad=\quad 2317.60 \times 10$

Rs 23176.00 
Table 8: Percentage of expenditure for each cost item

\begin{tabular}{lrr}
\hline Item & $\begin{array}{r}\text { Cost } \\
\text { (SLR) }\end{array}$ & $\begin{array}{r}\text { Percentage } \\
\mathbf{( \% )}\end{array}$ \\
\hline Medication, PPE, & \\
and surgical consumables & 483,927 & 2.9 \\
Investigations & 683,100 & 4.1 \\
Patient meals & $2,814,255$ & 16.9 \\
Staff salaries & $4,979,135$ & 29.9 \\
Overheads & $1,593,163$ & 9.6 \\
Transport & $5,950,700$ & 35.8 \\
miscellaneous & 111,287 & 0.67 \\
\hline \multicolumn{3}{c}{} \\
\hline
\end{tabular}

\section{Discussion}

The cost of treating Covid patients at CTC, DGHH was exceptionally low(Rs 23176) when compared to other countries. In Philippines, it is around Rs 172000 (6). This low cost may be due to treating both asymptomatic and symptomatic patients, functioning under minimal staff with maximum efficiency at CTC, DGHH.

The cost of drugs is the major contributor to the direct medical cost (7). Hospitals in the United States spent 207100 rupees per COVID-19 patient on medication, although CTC DGHH only spent 675.40 rupees (8). This difference may be due to treating both symptomatic and asymptomatic patients at CTC, DGHH, which significantly reduced the drug cost.

Transport cost accounted for $35.8 \%$ of the total cost. This may be relatively high when compared to other cost items. Transporting Covid patients from all parts of the country to CTC, DGHH and sending them home by using ambulances was the reason for this high cost.

However, cost per inpatient day and total cost for the patient at CTC, DGHH was exceptionally low when compared to other countries and even private sector of Sri Lanka.

\section{Conclusion}

Treating Covid 19 patient is an economic burden to any health system. Although, its economic impact is high, there were very few researches to assess it. Therefore, this retrospective Costing study was conducted to assess the cost incurred in managing Covid 19 patients at Covid treatment centre in DGH, Hambantota. Treatment cost was extremely low at DGH, Hambantota and only 23000 rupees were spent for one patient. The cost for drugs, PPE and surgical consumables was comparatively low while transport cost was relatively high.

\section{References}

1. WHO. Novel coronavirus (COVID-19) situation report - 101. https://www. who.int/docs/defaultsource/coronaviruse/situation-reports/20200430sitrep-101- covid-19.pdf?sfvrsn=2ba4e093_2. Accessed 28 February 2021

2. Epidemiology unit, Sri Lanka, Corona related documents. Available at: https://www.epid.gov.lk/ web/images/pdf/Circulars/Corona_virus/corona_ virus_press_release_english.pdf

3. Tian S, Hu N, Lou J, Chen K, Kang X, Xiang Z, et al. Characteristics of COVID19 infection in Beijing. J Inf Secur. 2020;80(4):401-6.

4. Wu Z, McGoogan JM. Characteristics of and important lessons from the coronavirus disease 2019 (COVID-19) outbreak in China: summary of a report of 72314 cases from the Chinese Center for Disease Control and Prevention. JAMA. 2020;323(13):1239-42.

5. Xie J, Tong Z, Guan X, Du B, Qiu H, Slutsky AS. Critical care crisis and some recommendations during the COVID-19 epidemic in China. Intensive Care Med. 2020;46(5):837 -40.

6. How much does COVID-19 treatment cost, and how much will PhilHealth cover? Trishia Billones, Jessica Fenol and Warren de Guzman, ABS-CBN News . Posted at Apr 132020 06:02 PM I Updated as of mar 152021 11:14 PM. https://news.abs-cbn. com/business/04/13/20/how-much-does-covid19-treatment-cost-and-how-much-will-philhealthcover.

7. Treatment of coronavirus disease 2019 in Shandong, China: a cost and affordability analysis Xue-Zheng Li1,2,3, Feng Jin2,3, Jian-Guo Zhang4 , Yun-Feng Deng2,3, Wei Shu5, Jing-Min Qin2,3, Xin Ma1,2,3* and Yu Pang. . Infectious Diseases of Poverty (2020) 9:78 https://doi.org/10.1186/ s40249-020-00689-0

8. Chad Terhune (2020). Drug costs for COVID-19 patients plunge at U.S. hospitals, but may rise. https://www.reuters.com/article/us-healthcoronavirus-drug-costs-idUSKCN25F1BW. 